\title{
ANALYSIS OF PROJECT SUCCESS FACTORS IN CONSTRUCTION INDUSTRY
}

\author{
Murat GUNDUZ ${ }^{\mathrm{a}}$, Ahmad Mohammed Ali YAHYA ${ }^{\mathrm{b}}$ \\ ${ }^{a}$ Department of Civil Engineering, Qatar University, PO Box: 2713 Doha, Qatar \\ ${ }^{b}$ Civil Engineer, Petrofac International, Sharjah, UAE
}

Received 08 April 2014; accepted 16 May 2015

\begin{abstract}
A great emphasis has taken place to identify and analyse the factors that have been affecting the success and the failure of construction projects in recent decades. As a project-based industry, construction has heavily invested in such research. Moreover, the construction industry suffers the most to meet deadlines and budgets limits. The objective of this paper is to identify the critical success factors in construction industry. The study focused on Middle East region. In order to achieve this objective, 25 project success factors were identified by reviewing related literature. The factors were assessed for their impact and contribution to the actual performance of the project on three criteria: schedule, cost, and quality. Then a questionnaire was developed and sent to different experts in the construction industry. The collected data of 111 responses was then analysed statistically by using different tools such as: importance index, Spearman's rank correlation factor and T-test. As a result, company's technical capacity and scope and work definition were ranked the most important factors. The results of this research may provide a great assistance to professionals and researchers in identifying the critical factors in the construction industry.
\end{abstract}

Keywords: project success factors, construction industry, importance index.

JEL Classification: C83, L74, O22.

\section{Introduction}

The construction industry is related to risks, just as any other global industry. Due to the complex nature and the participation of different parties in construction, an extra risk is added to construction projects (PMI 2004). In the last few decades, construction projects have become more challenging to the contractors and clients due to tough budget and scheduling requirements.

Sustainable development represents a major challenge of the 21st century. Organizab tions use projects to implement strategic corporate objectives; therefore, exploring sus-

Corresponding author Murat Gunduz

E-mail:mgunduz@qu.edu.qa 
tainable development from a project management perspective is imperative (Ghosh et al. 2014). Project managers can increase the chances of completing the projects successfully and meeting all the requirements by applying management tools during the planning and the execution phases of the project (Jaselskis, Ashley 1991). Perhaps the best known approach for tackling the human and organizational aspects of projects is through the use of critical success factors but although the approach has very many champions it is not without its critics (Fortune, White 2006). The objective of this paper is to determine the most significant project success factors for successful project management. This is achieved first by reviewing literature to capture project success factors and then developing a survey. The collected data were analyzed statistically and recommendations were developed for construction professionals and researchers.

The fact that the construction industry suffers the most to meet deadlines and budgets necessitate a great attention to identify critical success factors. UAE is one of the biggest and most developing markets in the world. The importance of UAE market and its impact on the growth in the Middle East region is significant. The contribution of this paper is that is can provide a deep focus on the critical success factors that affect construction projects in UAE and Middle East. Moreover, it provides wide range of comparisons from different perspectives to provide clear idea about all attributes that affect a project. The final results of this research will allow different project participants to work together to execute and complete the project successfully and meet their objectives. This study is unique in terms of addressing a wide variety of project success factors collected through past research. It is also unique in terms of its outcomes relating to Middle East region as well. The significant factors captured by the research would be a key indicator for the industry professionals for a better project success.

\section{Literature review}

A number of studies were carried out to determine the project critical success factors while some scholars prefer to study the project failure factors or causes of failure. Some studies investigated the impact of technical factors such as scope and work definition as well as planning (Jha, Iyer 2007; Doloi et al. 2012; Chan et al. 2004; Atkinson 1999; Sambasivan, Soon 2007; Leung et al. 2004; Turner, Cochrane 1993). Other body of research studied the effect that different stakeholders may have on the project outcome; i.e. the client consultation and support (Jha, Iyer 2007; Chan et al. 2004; Tabish, Jha 2012; Munns, Bjeirmi 1996), top management support (Jha, Iyer 2007; Yang et al. 2011; Chua et al. 1999), and project manager capabilities and commitment (Kog, Loh 2012; Chan et al. 2004; Ogunlana et al. 2002; Tabish, Jha 2012; Yang et al. 2011; Chua et al. 1999; Jaselskis, Ashley 1991). Some researchers studied the project management techniques (Chan et al. 2004; Chua et al. 1997; Munns, Bjeirmi 1996; Jaselskis, Ashley 1991) and the effect of team members (Kog, Loh 2012; Doloi et al. 2012; Tabish, Jha 2012), team motivation (Kog, Loh 2012; Tabish, Jha 2012; Chua et al. 1999), and personnel selection and training (Jha, Iyer 2007; Chan et al. 2004; Tabish, Jha 2012; Munns, Bjeirmi 1996). Others investigated the impact of soft skills such as communication between different stakeholders (Bryde, Robinson 2005; Yang 
et al. 2010; Doloi et al. 2012; Wang, Huang 2006; Chua et al. 1999; Leung et al. 2004), or external factors that might affect the project success, such as; political conflicts and corruption, harsh climate conditions and environment, unforeseen conditions (Chan et al. 2004; Tabish, Jha 2012; Chua et al. 1999; Songer, Molenaar 1997; Yu et al. 2006; Pinto 1985).

Table 1 presents the factors selected from previous literature with the corresponding references.

Table 1. Project success factors

\begin{tabular}{|c|c|}
\hline Factors & References \\
\hline $\begin{array}{l}\text { Effective communication } \\
\text { between stakeholders }\end{array}$ & $\begin{array}{l}\text { Bryde, Robinson (2005), Yang et al. (2010), Doloi et al. (2012), } \\
\text { Wang, Huang (2006), Chua et al. (1999), Leung et al. (2004) }\end{array}$ \\
\hline Company's financial strength & Alzahrani, Emsley (2013), Ye et al. (2009), Coskun et al. (2013) \\
\hline Company's technical capacity & Alzahrani, Emsley (2013), Ye et al. (2009) \\
\hline Scope and work definition & $\begin{array}{l}\text { Jha, Iyer (2007), Doloi et al. (2012), Chan et al. (2004), Leung } \\
\text { et al. (2004), Turner, Cochrane (1993) }\end{array}$ \\
\hline Clarity of the project mission & $\begin{array}{l}\text { Jha, Iyer (2007), Chua et al. (1999), Turner, Cochrane (1993), } \\
\text { Gudiene et al. (2014) }\end{array}$ \\
\hline Planning efforts & $\begin{array}{l}\text { Jha, Iyer (2007), Doloi et al. (2012), Atkinson 1999), } \\
\text { Sambasivan, Soon (2007) }\end{array}$ \\
\hline Adequate risk analysis & $\begin{array}{l}\text { Cooke-Davies (2002), PMI (2004), Barber (2005), Wang et al. } \\
\text { (2004), Yun et al. (2015) }\end{array}$ \\
\hline Effective scheduling & $\begin{array}{l}\text { Jha, Iyer (2007), Kog, Loh (2012), Tabish, Jha (2012), Jaśkowski, } \\
\text { Biruk (2011) }\end{array}$ \\
\hline Effective project briefing & Yu et al. (2006) \\
\hline $\begin{array}{l}\text { Adequacy of plans and } \\
\text { specifications }\end{array}$ & $\begin{array}{l}\text { Jha, Iyer (2007), Kog, Loh (2012), Chua et al. (1999), Sanvido } \\
\text { et al. (1992) }\end{array}$ \\
\hline $\begin{array}{l}\text { Effective procurement and } \\
\text { tendering methods }\end{array}$ & $\begin{array}{l}\text { Chan et al. (2004), Pocock et al. (1997), Dissanayaka, } \\
\text { Kumaraswamy (1999), Mitkus, Trinkūnienè (2008) }\end{array}$ \\
\hline $\begin{array}{l}\text { Adequate project management } \\
\text { techniques. }\end{array}$ & $\begin{array}{l}\text { Chan et al. (2004), Chua et al. (1997), Munns, Bjeirmi (1996), } \\
\text { Jaselskis, Ashley (1991), Gudiene et al. (2014) }\end{array}$ \\
\hline Control system & Jha, Iyer (2007), Tabish, Jha (2012), Chua et al. (1999) \\
\hline Commitment to the project & Kog, Loh (2012), Doloi et al. (2012) \\
\hline $\begin{array}{l}\text { The client consultation and } \\
\text { support }\end{array}$ & $\begin{array}{l}\text { Jha, Iyer (2007), Chan et al. (2004), Tabish, Jha (2012), Munns, } \\
\text { Bjeirmi (1996) }\end{array}$ \\
\hline Top management support & $\begin{array}{l}\text { Jha, Iyer (2007), Yang et al. (2011), Chua et al. (1999), Zou et al. } \\
\text { (2014) }\end{array}$ \\
\hline $\begin{array}{l}\text { Project manager capabilities and } \\
\text { commitment }\end{array}$ & $\begin{array}{l}\text { Kog, Loh (2012), Chan et al. (2004), Ogunlana et al. (2002), } \\
\text { Tabish, Jha (2012), Yang et al. (2011), Chua et al. (1999), } \\
\text { Jaselskis, Ashley (1991) }\end{array}$ \\
\hline Effective site management & $\begin{array}{l}\text { Doloi et al. (2012), Chua et al. (1999), Jaselskis, Ashley (1991), } \\
\text { Kaming et al. (1997) }\end{array}$ \\
\hline $\begin{array}{l}\text { Team motivation (rewards and } \\
\text { incentives) }\end{array}$ & Kog, Loh (2012), Tabish, Jha (2012), Chua et al. (1999) \\
\hline Effective technical review & Chua et al. (1997), Munns, Bjeirmi (1996), Cooke-Davies (2002) \\
\hline
\end{tabular}


End of Table 1

\begin{tabular}{ll}
\hline \multicolumn{1}{c}{ Factors } & \multicolumn{1}{c}{ References } \\
\hline Personnel selection and training & $\begin{array}{l}\text { Jha, Iyer (2007), Chan } \text { et al. (2004), Tabish, Jha (2012), Munns, } \\
\text { Bjeirmi (1996) }\end{array}$ \\
\hline $\begin{array}{l}\text { Completion of design at the } \\
\text { construction start }\end{array}$ & Chua et al. (1997), Sanvido et al. (1992) \\
\hline Political conflicts and corruption & $\begin{array}{l}\text { Chan } \text { et al. (2004), Tabish, Jha (2012), Chua et al. (1999), } \\
\text { Songer, Molenaar (1997), Walker (1995), Pinto (1985) }\end{array}$ \\
\hline $\begin{array}{l}\text { Harsh climate conditions and } \\
\text { environment }\end{array}$ & $\begin{array}{l}\text { Chan } \text { et al. (2004), Tabish, Jha (2012), Chua et al. (1999), } \\
\text { Songer, Molenaar (1997), Walker (1995), Pinto (1985) }\end{array}$ \\
\hline Unforeseen conditions & $\begin{array}{l}\text { Chan } \text { et al. (2004), Tabish, Jha (2012), Chua } \text { et al. (1999), } \\
\text { Songer, Molenaar (1997), Walker (1995), Pinto (1985) }\end{array}$ \\
\hline
\end{tabular}

For the current study, a survey was developed to identify the most critical success factors in the UAE and the Middle East construction industry. The success factors were determined based on the findings of the literature review.

\section{Methodology}

Reviewing past literature on project success factors was the first step in the research methodology. 25 different success factors from the literature review were identified. A survey was developed based on Likert scale consisting of importance scale and frequency scale, and general information section. The Likert scales were used as $(1=$ Very Low, $2=$ Low, 3 Average, $4=$ High, $5=$ Very High $)$ for the importance and $(1=$ Never, $2=$ Rarely, $3=$ Sometimes, 4 = Often, 5 = Always) for the frequency section. General information section consisted of seven questions to get an overview about the respondents that were used for categorization purposes. The web-survey was then developed and the link for the websurvey was sent to respondents in different countries and companies.

111 responses were collected and the date was extracted from the website. The collected data was analyzed using statistical techniques such as Relative Importance Index (RII) and Frequency Index (FI). Frequency Adjusted Importance Index (FAII) was also developed take into account the effect of RII and FI together. Spearman's rank correlation factor and T-test were also applied on collected data. Finally, the results of the statistical analysis were interpreted to provide valuable information to evaluate and rank the factors based on their importance.

\section{Data characteristics}

The survey collected data with the help of a professional web site. The respondents followed the instructions on the web site to fill the form. The website was shared among various media to increase the response rate. 111 respondents filled out the survey form. The technical background of the respondents varies as: 20 responses had superstructure background, 11 responses had infrastructure, 62 responses had oil and gas, 7 had industrial construction, 
and 11 for other industries such as research institutes, master planning and architectural design consultancies. One of the evaluation criteria of the data collected from the survey is the company profile. In the survey, 43 responses are client or client representative and 68 responses are contractors. There were 32 responses from Middle East and 79 responses from the UAE region. The survey presents the years of experience in 4 categories, from fresh graduate with zero years of experience to 5 years, from 6 years to 10 years, from 11 years to 15 years, and more than 15 years. In the analysis and comparison part of this study, the four categories will be combined to form only two categories; less than 10 years' experience and more than 10 years' experience. Table 2 shows the count and the percentages based on the years of experience.

Table 2. Responses based on years of experience

\begin{tabular}{ccc}
\hline Years of experience & Response percent & Response count \\
\hline $0-5$ & $26 \%$ & 29 \\
\hline $6-10$ & $12 \%$ & 13 \\
\hline $11-15$ & $15 \%$ & 17 \\
\hline more than 15 & $47 \%$ & 52 \\
\hline
\end{tabular}

\section{Statistical data analysis methodology}

A total of 25 factors affecting the project success and performance were identified through literature review in the construction industry. The survey is based on Likert Scale. The section is divided into two sub-sections; importance scale and the frequency scale. The respondents were asked to rate the factor importance (the severity of this factor on the project success) and the frequency of considering and implementing this factor in real life. Both scales consist of five points scale.

\subsection{Relative Importance Index (RII)}

The relative importance index was used to measure the importance of different attributes. Doloi, Sawhney, Iyer, and Rentala used the relative importance index to analyze factors affecting delays in Indian construction projects (Doloi et al. 2012). The Five-point Likert scale ranges from 1 (very low importance) to 5 (very high importance) was implemented. Then, the relative importance index for each factor was calculated based on the following formula:

$$
\mathrm{RII}=\frac{\sum \mathrm{W}}{\mathrm{A}^{\star} \mathrm{N}},
$$

where: $\mathrm{W}$ - weight given to each factor by the respondents (1 to 5); A - the highest weight (in this case is 5); $\mathrm{N}$ - total number of respondents.

Then the factors were ranked based on the values of the RII. The value of the RII will vary from 0 to 1 , the greater the value the higher the importance of each factor will be. 


\subsection{Frequency Index (FI)}

This Index is similar to Relative Importance Index, where the scale was adjusted to $(1=$ Never, 2 = Rarely, 3 = Sometimes, 4 = Often, 5 = Always) (Assaf, Al-Hejji 2006). The formula is given below.

$$
\text { Frequency Index }(\mathrm{FI})(\%)=\sum \mathrm{W}\left(\frac{\mathrm{n}}{\mathrm{N}}\right) * \frac{100}{5},
$$

where: $\mathrm{W}$ - weight given to each factor by the respondents (1 to 5); $\mathrm{n}$ - Frequency of the responses; $\mathrm{N}$ - total number of responses.

\subsection{The Frequency Adjusted Importance Index (FAII)}

The frequency adjusted importance index is a similar ranking technique which used to rank different attributes; however it considered the frequency of occurring or the frequency of considering and implementing and the importance of the factors at the same time. In order to find the FAII, the Frequency index and the severity index need to be calculated. Based on the both the frequency index and the RII (or severity index), the frequency adjusted importance index will be calculated as below.

$$
\text { FAII }=\text { RII * (F.I.) }(\%),
$$

FAII is considered more accurate since it considers both the importance and the frequency of each factor. Due to the accuracy and the precision, FAII will be used as the main ranking tool in this paper.

\subsection{Spearman rank correlation factor}

Spearman's rank correlation factor is usually used to check the accurateness and precision of a data. Spearman's rank correlation test is a non-parametric test. Nonparametric tests are also referred to as distribution free tests. It does not require the normality of distribution or the homogeneity of the data which is considered as a big advantage over other approaches. The Spearman's correlation measure the strength of the relationship between different parties regarding different attributes (in the research the success factors are the attributes). It can be calculated by applying the following formula.

$$
\mathrm{r}=1-\left[\left(6 \sum \mathrm{d}^{2}\right) /(\mathrm{n} 3-\mathrm{n})\right]
$$

where $r$ is the Spearman rank correlation coefficient between two parties, $d$ is the difference between ranks assigned to variables for each cause, and $n$ is the number of pairs of rank (in this paper it equals to the number of factors which is 25). It is used to show the degree of agreement between the different parties. The correlation coefficient varies between +1 and -1 , where +1 implies a perfect positive relationship (agreement), while -1 results from a perfect negative relationship (disagreement).

It is used to check the correlation between two different criteria. This tool was implemented to check the accuracy and the relationship for client vs. contractors, UAE market vs. the region and 10 years' experience Vs less than 10 years' experience. 


\subsection{T-Test}

The T-Test is used to evaluate how close or related two different groups. It determines whether there is a significant difference between the means of two unrelated groups. The formula is as follows:

$$
\mathrm{t}=\frac{\overline{\mathrm{x}}_{1}-\overline{\mathrm{x}}_{2}}{\sqrt{\frac{\mathrm{S}_{1}^{2}}{\mathrm{n}_{1}}+\frac{\mathrm{S}_{2}^{2}}{\mathrm{n}_{2}}}},
$$

where: $\bar{x}_{1}-$ Mean of first set of values; $\bar{x}_{2}-$ Mean of second set of values; $S_{1}-$ Standard deviation of first set of values; $S_{2}$ - Standard deviation of second set of values; $n_{1}-$ Total number of values in first set; $\mathrm{n}_{2}$ - Total number of values in second set.

The significant level (alpha value) is set to be 0.05 . The main value that is used to evaluate the groups is the significance value ( $p$-value). If the value is greater than 0.1 , the group variance can be treated as the same and no significant difference exists. However, if the value is less than 0.1 then a significant difference exists and different group variances.

\section{Data analysis}

The aim of any project is to be completed successfully and meet all the success criteria (cost, time, and quality). The aim of this paper is to identify the top critical factors that contribute in completing the project successfully. From the literature 25 factors was identified, and each factor was evaluated individually based on it is importance and the frequency of implementing/considering these factors during the real time of execution.

Table 3 shows each factors and relative responses regarding the importance and the frequency. It also shows the frequency adjusted importance index value and the corresponding rank for that value. Table 3 shows a summary of the survey form developed and its major outcomes.

Table 3. Importance Index values and Ranking for FAII

\begin{tabular}{lcccc}
\hline \multicolumn{1}{c}{ Factors } & RII (\%) & FI (\%) & FAII (\%) & Ranking Based on FAII \\
\hline Company's technical capacities & 86.31 & 89.01 & 76.82 & 1 \\
\hline Scope and work definition & 83.78 & 85.05 & 71.25 & 2 \\
\hline Control system & 82.88 & 83.42 & 69.14 & 3 \\
\hline Effective site management & 83.42 & 82.52 & 68.84 & 4 \\
\hline Project manager capabilities and commitment & 84.14 & 81.8 & 68.83 & 5 \\
\hline Company's financial strength & 81.44 & 82.88 & 67.5 & 6 \\
\hline Planning efforts & 78.56 & 83.6 & 65.68 & 7 \\
\hline Effective scheduling & 79.1 & 82.88 & 65.56 & 8 \\
\hline Commitment to the project & 79.46 & 81.8 & 65 & 9 \\
\hline Adequate project management techniques & 80.54 & 79.64 & 64.14 & 10 \\
\hline Adequacy of plans and specifications & 77.84 & 80.72 & 62.83 & 11 \\
\hline
\end{tabular}


End of Table 3

\begin{tabular}{lcccc}
\hline \multicolumn{1}{c}{ Factors } & RII (\%) & FI (\%) & FAII (\%) & Ranking Based on FAII \\
\hline Effective procurement and tendering methods & 79.1 & 78.74 & 62.28 & 12 \\
\hline Client consultation and support & 78.56 & 79.28 & 62.28 & 13 \\
\hline Effective communication between stakeholders & 79.1 & 78.2 & 61.85 & 14 \\
\hline Top management support & 78.38 & 76.76 & 60.16 & 15 \\
\hline Adequate risk analysis & 77.12 & 77.48 & 59.75 & 16 \\
\hline Clarity of project mission & 77.48 & 77.12 & 59.75 & 17 \\
\hline Effective technical review & 78.2 & 76.4 & 59.74 & 18 \\
\hline Personnel selection and training & 78.74 & 75.86 & 59.73 & 19 \\
\hline Completion of design at the construction start & 75.5 & 76.22 & 57.54 & 20 \\
\hline Effective project briefing & 72.79 & 73.15 & 53.25 & 21 \\
\hline Team motivation & 76.22 & 69.55 & 53.01 & 22 \\
\hline Harsh climate conditions and environment & 64.68 & 65.59 & 42.42 & 23 \\
\hline Political conflicts and corruption & 60.9 & 54.59 & 33.25 & 24 \\
\hline Unforeseen conditions & 58.74 & 55.5 & 32.6 & 25 \\
\hline
\end{tabular}

Company's technical capacity was ranked as the most important factor based on both techniques RII, FI and FAII. According to the respondents, the technical capacity throughout the different stages of a project will lead to a more successful project. However, the unforeseen conditions which (natural disasters, wars, Economical crises, sudden changes of laws and regulations etc.) was ranked as the least important factor.

\subsection{Spearman's rank correlation factors}

To address the differences between the two groups of data Spearman's rank correlation factor $(r)$ is used. Spearman's rank correlation factor is usually used to check the accurateness and precision of a data. It measures the strength of the relationship between different parties regarding different attributes (in the research the success factors are the attributes). The correlation coefficient varies between +1 and -1 , where +1 implies a perfect positive relationship (agreement), while -1 results from a perfect negative relationship (disagreement). Just as an example, in previous literature, researchers used Spearman's test and TTest analysis frequently. Kog and Loh (2012) identified the top 10 critical success factors out of 67 factors by surveying experts with different backgrounds. The factors were identified through previous researches and literature and ranked by the respondents. Moreover, Spearman ranking coefficient was used to study the consistency of the results and whether they are related or not. The views of different professionals are based on their experience and involvement in different construction projects. Doloi et al. (2012) identified 7 critical delay (failure) factors in the Indian construction industry. A questionnaire and personal interviews were conducted based on 45 factors. Factor analysis and regression modeling were implemented to evaluate the importance of the factors and hence the relative Importance Index were used to ranked the factors based on their importance. Moreover, Spearman 
rank correlation was used to identify the relationship between the factors. In this research the groups were tested for UAE vs. Middle East (excluding UAE), clients vs. contractors, professionals with more than 10 years vs. Less than 10 years. Spearman's rank correlation factors for these three comparisons are shown in Table 4.

Table 4. Spearman's rank correlation factors

\begin{tabular}{lc}
\hline \multicolumn{1}{c}{ Compared Groups } & Spearman's rank correlation factors \\
\hline UAE vs. Middle East (excluding UAE) & 0.886154 \\
\hline Clients vs. Contractors & 0.882692 \\
\hline Professionals with more than 10 years vs. Less than 10 years & 0.836154 \\
\hline
\end{tabular}

High correlations values show that the categories for three different cases suggest almost the same ranking. There are some minor differences in views and these will be tested by $\mathrm{t}$-statistics in the next section.

\subsection{T-Test analysis}

The $t$ test is used to determine if there is a significant difference between the means of two independent (unrelated) groups. The test is used to compare the results of UAE market with Middle East market, contractor's perspective with the client's perspective, and professional with less than 10 years' experience perspective and more than 10 years' experience perspective.

The significant level (alpha value) is set to be 0.10 . The main value that is used to evaluate the groups is the significance value ( $p$-value). If the value is greater than 0.1 , the group variance can be treated as the same and no significant difference exists. However, if the value is less than 0.1 then a significant difference exists and different group variances.

Table 5 shows the results of the T-test conducted on three groups (the UAE market vs the Middle East market, the client vs. Contractor, and more than 10 years' experience

Table 5. T-test results for three groups

\begin{tabular}{lccccc}
\hline & \multicolumn{2}{c}{ UAE } & \multicolumn{2}{c}{ Middle East } \\
\hline \multicolumn{1}{c}{ Factors } & Mean & Variance & Mean & Variance & P-value \\
\hline Scope and work definition & 4.2568 & 0.5770 & 4.0313 & 0.5474 & 0.0791 \\
\hline Clarity of project mission & 4.0270 & 0.6568 & 3.6563 & 1.3942 & 0.0563 \\
\hline Effective project briefing & 3.6486 & 0.5872 & 3.4375 & 0.5766 & 0.0975 \\
\hline Adequacy of plans and specifications & 4.0270 & 0.5472 & 3.6563 & 1.1361 & 0.0402 \\
\hline Effective procurement and tendering methods & 4.0135 & 0.7532 & 3.7813 & 0.6925 & 0.0989 \\
\hline & \multicolumn{5}{c}{ Client } \\
\hline Company's Technical capacities & 4.4500 & 0.3564 & 4.2703 & 0.5013 & 0.0773 \\
\hline Project manager capabilities and commitment & 4.3500 & 0.4897 & 4.1216 & 0.6288 & 0.0582 \\
\hline & More than & 10 years & Less than 10 years & \\
\hline Completion of design at the construction start & 3.8696 & 0.6151 & 3.6190 & 0.9733 & 0.0831 \\
\hline Adequate project management techniques & 4.1014 & 0.5631 & 3.9048 & 0.4297 & 0.0751 \\
\hline
\end{tabular}


vs less than 10 years' experience). Comparison among the means and the $\mathrm{p}$ value of each significant factor are shown in the table for each three group. The factors that are not statistically significant are excluded from the table.

\section{Discussion of results}

Table 3 shows the ranking of the factors based on the results of the Frequency Adjusted Importance Index. Company's technical capacity came out to be the most important success factor. This might be an indication that the technical skills whether they belong to a client or contractor would lead to a successful project. Scope and work definition is another important factor that contributes in finishing the project successfully. Having a clear definition about what is to be done and what is required from each party involved in the project play an important role in effective project management. Moreover, would avoid variations and disputes that may lead to major delays or increase in project cost. Control systems came out to be the third important factor. It is clear that better controlled projects will lead to success. This shows how important it is to identify deviations, evaluate possible alternative course of actions and take appropriate corrective actions to get back on track and finish successfully. Effective site management is ranked in the fourth place. In construction project, the site people are the key players in the execution of any project. Having the right people on site will help in pushing the project to be completed as planned. Project manager capabilities and commitment comes as the fifth most important factor. The project manager is the leader of the project who controls all aspects of the project, his/her experience, characteristics, and his/her commitment to project can lead at the end to success completion of a project. However, the unforeseen conditions which (natural disasters, wars, economic crises, sudden changes of laws and regulations etc.), political conflicts and corruption and harsh climate conditions and environment were ranked as the least important factors. This may be due to familiarity with the project location, its local economy, legislation and geographical conditions.

As the next statistical analysis, Spearman's rank correlation factor analysis was carried out. The data was grouped in various categories to see if there is statistical difference between groups for UAE vs. Middle East (excluding UAE), clients vs. contractors, respondents with more than 10 years vs. less than 10 years' experience. The high correlation suggests that these three different categories think closely but there are still minor deviations. These deviations were captured by the t-test statistics for these three groups. The result of t-test statistics is represented in Table 5.

As a result of the T-test, there are five significant factors for comparison UAE vs. Middle East (excluding UAE). It can be easily seen that the mean values for UAE is highest for all these five factors. UAE pays more attention to scope definition and clarity of project mission, adequacy of plans and specifications, project briefings and procurement and tendering methods.

When it comes to clients, they care more about capabilities of company and project manager. They relate these two capacity terms with project success. 
More experienced professionals also think that adequate management techniques will lead success. Moreover, design completion at construction start is also significant for experienced professionals. Gunduz and Hanna (2005) also stated that the percent design complete prior to construction plays an important role in the project.

Finally it was observed with the importance index that company's technical capacities, scope and work definition, control system, effective site management and project manager's capabilities and commitment were the top 5 success factors ranked by the respondents. It is recommended that the management team pays utmost attention to these 5 factors for a better project success.

\section{Limitations, recommendations and future work}

Further improvement is to be done to this research. The number of respondents is to be increased and the survey would be sent to more professionals with various backgrounds and different industry experiences. This research provides implications for theory, practice and policy. Success factors may be investigated as case studies where recently completed projects would be evaluated through interviews.

This research has implications for policy making. The success factors that keep showing up as the significant factors may draw policy makers' attention. The gap between academia and industry and public authorities could be bridged through further communication. Companies may provide early training to their employees taking into consideration the output of the research.

The importance of this research to developed countries is limited. It is recommended by the authors that a research is carried out in the context of developing countries.

\section{Conclusions}

This paper identifies and assesses the critical project success factors in construction projects. The study is focused on the Middle East region and the UAE market specially. The factors were assessed by their impact and contribution to the actual performance of the project on three criteria; schedule, cost, and quality. 25 factors were identified through literature review. These factors were evaluated by the survey respondents based on their impact and the frequency. Statistical techniques such as importance index, Spearman's rank correlation factor and T-test were used to measure and quantify the importance of the success factors. A frequency adjusted importance index was also introduced with this study.

This study covers an extensive list of project success factors and tries to capture the most significant ones through various data analysis tools. The construction industry and researchers may benefit from the outcomes of this research by paying utmost attention to the critical factors identified by this study. The construction industry may pay plan and manage their projects based on the most significant factors in this research. Moreover, the academia may perform more research on the most critical factors determined by this research. The industry may also pay attention to the difference between factors based on their project locations. 


\section{References}

Alzahrani, J. I.; Emsley, M. W. 2013. The impact of contractors' attributes on construction project success: a post construction evaluation, International Journal of Project Management 31: 313-322. http://dx.doi.org/10.1016/j.ijproman.2012.06.006

Assaf, S. A.; Al-Hejji, S. 2006. Causes of delay in large construction projects, International Journal of Project Management 24: 349-357. http://dx.doi.org/10.1016/j.ijproman.2005.11.010

Atkinson, R. 1999. Project management: cost, time and quality, two best guesses and a phenomenon, its time to accept other success criteria, International Journal of Project Management 17(6): 337-342. http://dx.doi.org/10.1016/S0263-7863(98)00069-6

Barber, R. 2005. Understanding internally generated risks in projects, International Journal of Project Management 23(8): 584-590. http://dx.doi.org/10.1016/j.ijproman.2005.05.006

Bryde, D. J.; Robinson, L. 2005. Client versus contractor perspectives on project success criteria, International Journal of Project Management 23: 622-629. http://dx.doi.org/10.1016/j.ijproman.2005.05.003

Chan, A. P. C.; Scott, D.; Chan, A. P. L. 2004. Factors affecting the success of a construction project, ASCE Journal of ConstructionEngineering and Management 130(1): 153-155. http://dx.doi.org/10.1061/(ASCE)0733-9364(2004)130:1(153)

Chua, D. K. H.; Loh, P. K.; Kog, Y. C.; Jaselskis, E. J. 1997. Neural networks for construction project success, Expert Systems with Applications 13(4): 317-328. http://dx.doi.org/10.1016/S0957-4174(97)00046-8

Chua, D. K. H.; Kog, Y. C.; Loh, P. K. 1999. Critical success factors for different project objectives, ASCE Journal of Construction Engineering and Management 125(3): 142-150. http://dx.doi.org/10.1061/(ASCE)0733-9364(1999)125:3(142)

Coskun, H.; Erdis, E.; Demirci, M. 2013. Pricing policies as a marketing strategy in the construction industry: case study of Turkish companies, Technological and Economic Development of Economy 19(Supplement 1): S1-S21. http://dx.doi.org/10.3846/20294913.2013.821688

Cooke-Davies, T. 2002. The "real" success factors on projects, International Journal of Project Management 20: 185-190. http://dx.doi.org/10.1016/S0263-7863(01)00067-9

Dissanayaka, S. M.; Kumaraswamy, M. M. 1999. Evaluation of factors affecting time and cost performance in Hong Kong building projects, Engineering, Construction and Archetictural Management 6(3): 287-298. http://dx.doi.org/10.1108/eb021119

Doloi, H.; Sawhney, A.; Iyer, K. C.; Rentala, S. 2012. Analysing factors affecting delays in Indian construction projects, International Journal of Project Management 30(4): 479-489. http://dx.doi.org/10.1016/j.ijproman.2011.10.004

Fortune, J.; White, D. 2006. Framing of project critical success factors by a systems model, International Journal of Project Management 24(1): 53-65. http://dx.doi.org/10.1016/j.ijproman.2005.07.004

Ghosh, S.; Buckler, L.; Skibniewski, M. J.; Negahban, S.; Kwak, Y. H. 2014. Organizational governance to integrate sustainability projects: a case study, Technological and Economic Development of Economy 20(1): 1-24. http://dx.doi.org/10.3846/20294913.2014.850755

Gudiene, N.; Banaitis, A.; Podvezko, V.; Banaitiene, N. 2014. Identification and evaluation of the critical success factors for construction projects in Lithuania: AHP approach, Journal of Civil Engineering and Management 20(3): 350-359. http://dx.doi.org/10.3846/13923730.2014.914082

Gunduz, M.; Hanna, A. S. 2005. Benchmarking change order impacts on productivity for electrical and mechanical projects, Building and Environment Journal 40(8): 1068-1075. http://dx.doi.org/10.1016/j.buildenv.2004.10.004

Jaselskis, E. J.; Ashley, D. B. 1991. Optimal allocation of project management resources for achieving success, ASCE Journal of Construction Engineering and Management 117(2): 321-340. http://dx.doi.org/10.1061/(ASCE)0733-9364(1991)117:2(321) 
Jaśkowski, P.; Biruk, S. 2011. The method for improving stability of construction project schedules through buffer allocation, Technological and Economic Development of Economy 17(3): 429-444. http://dx.doi.org/10.3846/20294913.2011.580587

Jha, K. N.; Iyer, K. C. 2007. Commitment, coordination, competence and the iron triangle, International Journal of Project Management 25(5): 527-540. http://dx.doi.org/10.1016/j.ijproman.2006.11.009

Kaming, P. F.; Olomolaiye, P. O.; Holt, G. D.; Harris, F. C. 1997. Factors influencing construction time and cost overruns on high-rise projects in Indonesia, Construction Management and Economics 15(1): 83-94. http://dx.doi.org/10.1080/014461997373132

Kog, Y. C.; Loh, P. K. 2012. Critical success factors for different components of construction projects, ASCE Journal of Construction Engineering And Management 138(4): 520-528. http://dx.doi.org/10.1061/(ASCE)CO.1943-7862.0000464 .

Leung, M. Y.; Ng, S. T.; Cheung, S. O. 2004. Measuring construction project participant satisfaction, Construction Management and Economics 22(3): 319-331. http://dx.doi.org/10.1080/0144619032000000000

Mitkus, S.; Trinkūniené, E. 2008. Reasoned decisions in construction contracts evaluation, Technological and Economic Development of Economy 14(3): 402-416. http://dx.doi.org/10.3846/1392-8619.2008.14.402-416

Munns, A. K.; Bjeirmi, B. F. 1996. The role of project management in achieving project success, International Journal of Project Management 14(2): 81-87. http://dx.doi.org/10.1016/0263-7863(95)00057-7

Ogunlana, S.; Siddiqui, Z.; Yisa, S.; Olomolaiye, P. 2002. Factors and procedures used in matching project managers to construction projects in Bangkok, International Journal of Project Management 20: 385-400. http://dx.doi.org/10.1016/S0263-7863(01)00017-5

Pinto, J. K. 1985. Project managers and major projects, Project Management Journal 3(4): 225-230. http://dx.doi.org/10.1016/0263-7863(85)90054-7

PMI. 2004. A guide to the project management body of knowledge [online], [cited 07 April 2014]. Available from Internet: www.pmi.org

Pocock, J. B.; Liu, L. Y.; Kim, M. K. 1997. Impact of management approach on project interaction and performance, ASCE Journal of Construction Engineering and Management 123(4): 411-418. http://dx.doi.org/10.1061/(ASCE)0733-9364(1997)123:4(411)

Sambasivan, M.; Soon, Y. 2007. Causes and effects of delays in Malaysian construction industry, International Journal of Project Management 25: 517-526. http://dx.doi.org/10.1016/j.ijproman.2006.11.007

Sanvido, V.; Parfitt, K.; Guveris, M.; Coyle, M. 1992. Critical success factors for construction projects, ASCE Journal of Construction Engineering and Management 118(1): 94-111. http://dx.doi.org/10.1061/(ASCE)0733-9364(1992)118:1(94)

Songer, A. D.; Molenaar, K. R. 1997. Project characteristics for successful public-sector design-build, ASCE Journal of Construction Engineering and Management 123(1): 34-40. http://dx.doi.org/10.1061/(ASCE)0733-9364(1997)123:1(34)

Tabish, S. Z.; Jha, K. N. 2012. Success traits for a construction project, ASCE Journal of Construction Engineering and Management 138(10): 1131-1138. http://dx.doi.org/10.1061/(ASCE)CO.1943-7862.0000538

Turner, J. R.; Cochrane, R. A. 1993. Goals-and-methods matrix: coping with projects ill defined goals and/or methods of achieving them, International Journal of Project Management 11(2): 93-102. http://dx.doi.org/10.1016/0263-7863(93)90017-H

Walker, D. H. T. 1995. An investigation into construction time performance, Construction Management and Economics 13(3): 263-274. http://dx.doi.org/10.1080/01446199500000030

Wang, S.; Dulaimi, M. F.; Aguria, M. Y. 2004. Risk management framework for construction projects in developing countries, Construction Management and Economics 22(3): 237-252.

http://dx.doi.org/10.1080/0144619032000124689 
Wang, X.; Huang, J. 2006. The relationships between key stakeholders' project performance and project success: perceptions of Chinese construction supervising engineers, International Journal of Project Management 24: 253-260. http://dx.doi.org/10.1016/j.ijproman.2005.11.006

Yang, L. R.; Huang, C. F.; Wu, K. S. 2011. The association among project manager's leadership style, teamwork and project success, International Journal of Project Management 29: 258-267. http://dx.doi.org/10.1016/j.ijproman.2010.03.006

Yang, J.; Shen, G. Q.; Drew, D. S.; Ho, M. 2010. Critical success factors for stakeholder management: construction practitioners' perspectives, ASCE Journal of Construction Engineering and Management 136(7): 778-786. http://dx.doi.org/10.1061/(ASCE)CO.1943-7862.0000180

Ye, J.; Hassan, T.; Carter, C.; Kemp, L. 2009. Stakeholders requirements analysis for a demand-driven construction industry [online], [cited 07 April 2014]. Available from internet: http://www.itcon.org

Yu, A. T. W.; Shen, Q.; Kelly, J.; Hunter, K. 2006. Investigation of critical success factors in construction project briefing by way of content analysis, ASCE Journal of Construction Engineering and Management 132(11): 1178-1186. http://dx.doi.org/10.1061/(ASCE)0733-9364(2006)132:11(1178)

Yun, S.; Jung, W.; Han, S. H.; Park, H. 2015. Critical organizational success factors for public private partnership projects - a comparison of solicited and unsolicited proposals, Journal of Civil Engineering and Management 21(2): 131-143. http://dx.doi.org/10.3846/13923730.2013.802715

Zou, W.; Kumaraswamy, M.; Chung, J.; Wong, J. 2014. Identifying the critical success factors for relationship management in PPP projects, International Journal of Project Management 32(2): 265-274. http://dx.doi.org/10.1016/j.ijproman.2013.05.004

Murat GUNDUZ. Dr is a professor of Civil Engineering Department at Qatar University. He completed a Master's degree in Construction Engineering and Management at Georgia Institute of Technology USA in 1998. He completed his PhD in the same area at the University of Wisconsin, Madison USA in 2002. His research interest is construction engineering and management. He is an editorial board member of ASCE Journal of Management in Engineering.

Ahmad Mohammed Ali YAHYA works at Petrofac International as a civil engineer. 